NOTE

\title{
Sea lion Otaria flavescens as host of the common vampire bat Desmodus rotundus
}

\author{
Alessandro Catenazzi ${ }^{1,2, *}$, Maureen A. Donnelly ${ }^{1}$ \\ ${ }^{1}$ Department of Biological Sciences, Florida International University, Miami, Florida 33199, USA \\ ${ }^{2}$ Present address: Department of Integrative Biology, University of California, Berkeley, \\ 3060 Valley Life Sciences Building \#3140, Berkeley, California 94720, USA
}

\begin{abstract}
We explored how the common vampire bat Desmodus rotundus is able to survive on hyper-arid rocky islands along the Peruvian coast in the absence of plants and terrestrial mammals. We used carbon and nitrogen stable isotope analyses on $D$. rotundus hairs and feces to assess the primary source of food, and compared our results with field observations near $D$. rotundus colonies. Data from stable isotope analyses were consistent with field observations, indicating that D. rotundus feeds on the South American sea lion Otaria flavescens, and occupies the third trophic level in a chain linking anchovies Engraulis ringens, O. flavescens, D. rotundus and a hippoboscid fly, Trichobius parasiticus. Our report demonstrates the importance of marine-derived resources for D. rotundus along the Peruvian coast.
\end{abstract}

KEY WORDS: Stable isotopes $\cdot \delta^{13} \mathrm{C} \cdot \delta^{15} \mathrm{~N} \cdot$ Trophic chain $\cdot$ Parasite $\cdot$ Marine subsidy $\cdot$ Pinniped Peru $\cdot$ Coastal desert

Resale or republication not permitted without written consent of the publisher

\section{INTRODUCTION}

The common vampire bat Desmodus rotundus (Desmodontinae; Phyllostomidae; Chiroptera) is a micropredator of large- and medium-sized terrestrial mammals (Greenhall 1988), attacking mostly herbivorous mammals and livestock, such as cattle, horses, mules, goats, swine and sheep (Goodwin \& Greenhall 1961). Low densities of $D$. rotundus in areas without livestock farming has been interpreted as a reflection of low host densities (Turner 1975, Lord 1988). However, livestock might not be the only hosts that enhance the local abundance of $D$. rotundus.

Here we report on large colonies of Desmodus rotundus feeding on a different type of mammalian host, the South American sea lion (Otaria flavescens; Otariidae; Carnivora). We worked on arid islands along the Peruvian coast where herbivorous mammals are virtually absent, and, after observing large colonies of D. rotundus, we explored how these bats were able to survive in areas lacking typical hosts. The islands where we conducted observations to identify the host of $D$. rotundus are part of the Peruvian coastal desert, one of the driest places on earth. Around the Paracas Peninsula and nearby islands in central Peru, average rainfall is $2 \mathrm{~mm} \mathrm{yr}^{-1}$ (Craig \& Psuty 1968), and the landscape is a barren land of rocks and sand. Vegetation is restricted to small valleys and fog oases, and does not support populations of medium- or large-sized mammals. The only potential hosts for $D$. rotundus in arid areas away from valleys and fog oases are foxes, but these tend to be rare in the desert and are absent from the coastal islands. However, the desert borders a highly productive coastal ecosystem (Tarazona \& Arntz 2001), fuelled by the upwelling associated with the PeruChile (Humboldt) current. The stark contrast in productivity levels between the adjacent terrestrial and marine ecosystems promotes energy and nutrient exchanges in several desert consumers (Koepcke \& Koepcke 1952, Catenazzi \& Donnelly 2007a,b). 
Our goal was to demonstrate how Desmodus rotundus, like other consumers in coastal arid Peru, takes advantage of marine-derived energy and nutrients for its diet. We present stable isotope data supporting the hypothesis of a short trophic chain linking marine plankton consumers (anchovies), marine predators (Otaria flavescens), terrestrial micropredators (D. rotundus) and terrestrial parasites (the hippoboscid fly Trichobius parasiticus, an ectoparasite of D. rotundus) across the marine and terrestrial ecosystems. The anchovy Engraulis ringens is the most common dietary item for O. flavescens around Sangayan (Soto et al. 2006). T. parasiticus is an ectoparasite of $D$. rotundus (Voigt \& Kelm 2006a). We discuss the relevance of this phenomenon to energy and nutrient flow from the marine to the terrestrial ecosystems.

\section{MATERIALS AND METHODS}

Study sites. We conducted our study on several guano islands along the coast of central Peru (see Table 1 for geographic coordinates; a KML file can be downloaded from http://acatenazzi.googlepages.com/ islands.kml) from July 2003 to March 2005. We conducted nighttime observations of Desmodus rotundus feeding upon or walking/hopping near Otaria flavescens on the following islands: Santa Rosa (19 to 21 July 2003), La Vieja (16 to 19 July, 15 to 19 September and 9 to 12 November 2003), Sangayan (6 to 9 July, 26 September to 2 October and 1 to 5 December 2003, 5 to 7 March 2005), Ballestas (26 to 29 July 2003), Asia (15 to 17 March 2005) and Guañape (26 February to
1 March 2005). Except for Sangayan, these are all guano islands with large populations of Guanay cormorants Phalacrocorax bougainvillii, Peruvian Boobies Sula variegata and/or Peruvian pelicans Pelecanus thagus. Sangayan does not have large colonies of these seabirds, but it harbors a large O. flavescens colony that includes 7000 to 15000 ind. There were 8600 ind. in March 2003, and 9955 ind. in February 2004 (Environmental Resources Management 2003, 2004). O. flavescens colonies were smaller than the Sangayan colony at the other visited sites.

Sample collection and stable isotope analyses. We collected Desmodus rotundus hair samples (each hair sample representing a single individual; live animals were captured by hand from roosting sites during the day) for stable isotope analysis in July 2003 on Santa Rosa, Sangayan and Ballestas islands (Table 1). In July 2003 and March 2005, we also collected Otaria flavescens hair samples (each hair sample representing a single individual; samples were collected from recently deceased individuals found inside the colony), Engraulis ringens (each sample included 3 to 5 individuals), Trichobius parasiticus (each sample consisting of approximately 3 to 5 flies) and $D$. rotundus fecal samples (integrating across unknown number of individuals and time) accumulated on the ground under the roosting site on Sangayan. Samples were sun-dried in the field, transported to the laboratory within 2 to $3 \mathrm{~d}$, and oven-dried for $48 \mathrm{~h}$ at $55^{\circ} \mathrm{C}$. We ground samples with mortar and pestle and defatted all samples with a solution of dichloromethane:methanol 9:1 in a sonicator. We used a Finnigan MAT Delta Plus continuous flow isotope ratio mass spectrometer at the SERC

Table 1. Islands where Desmodus rotundus was observed near pinniped colonies along coastal Peru, including sites where hair (Otaria flavescens, D. rotundus) and tissue samples (Engraulis ringens, Trichobius parasiticus) were collected for carbon and nitrogen stable isotope analyses

\begin{tabular}{|c|c|c|}
\hline Locality & Coordinates & Observations and sample collection \\
\hline Santa Rosa I. & $14^{\circ} 19^{\prime} \mathrm{N}, 76^{\circ} 09^{\prime} \mathrm{W}$ & $\begin{array}{l}\text { D. rotundus observed flying near } O \text {. flavescens on islets and at the base of cliffs. } \\
\text { Hair samples collected (D. rotundus) }\end{array}$ \\
\hline La Vieja I. & $14^{\circ} 17^{\prime} \mathrm{N}, 76^{\circ} 10^{\prime} \mathrm{W}$ & $\begin{array}{l}\text { Small colony of } D \text {. rotundus } \sim 300 \mathrm{~m} \text { from rocky shore used by } O \text {. flavescens; hair } \\
\text { samples collected (D. rotundus) }\end{array}$ \\
\hline Sangayan I. & $13^{\circ} 49^{\prime} \mathrm{S}, 76^{\circ} 27^{\prime} \mathrm{W}$ & $\begin{array}{l}\text { Four colonies of } D \text {. rotundus observed: small groups at the edge of } O \text {. flavescens } \\
\text { rookery, } 1 \text { large colony in rock crevice } \sim 150 \mathrm{~m} \text { from } O \text {. flavescens colony. Several } \\
\text { observations of } D \text {. rotundus feeding upon } O \text {. flavescens individuals at the edge of } \\
\text { the rookery. E. ringens, hair samples (O. flavescens and } D \text {. rotundus), T. parasiticus } \\
\text { collected }\end{array}$ \\
\hline Ballestas I. & $13^{\circ} 44^{\prime} \mathrm{N}, 76^{\circ} 24^{\prime} \mathrm{W}$ & $\begin{array}{l}\text { D. rotundus observed flying near } O \text {. flavescens on islets and at the base of cliffs. } \\
\text { Hair samples collected (D. rotundus) }\end{array}$ \\
\hline Asia I. & $12^{\circ} 47^{\prime} \mathrm{N}, 76^{\circ} 37^{\prime} \mathrm{W}$ & D. rotundus observed feeding upon an isolated $O$. flavescens male \\
\hline Guañape I. & $8^{\circ} 32^{\prime} \mathrm{N}, 78^{\circ} 58^{\prime} \mathrm{W}$ & D. rotundus observed flying around $O$. flavescens at the southern tip of the island \\
\hline
\end{tabular}


Stable Isotope Laboratory, Florida International University, Miami, and analyzed subsamples of 0.4 to $0.6 \mathrm{mg}$ of animal tissue. Carbon isotope values were expressed relative to the international standard Pee Dee Belemnite, and $\delta^{15} \mathrm{~N}$ relative to atmospheric air. We analyzed $18 \%$ of our samples in duplicate to determine accuracy of results. The average SD for replicate samples was $0.09 \%$ for $\delta^{13} \mathrm{C}$ and $0.14 \%$ for $\delta^{15} \mathrm{~N}$.

Statistical analyses. We used Student's $t$-tests or ANOVAs to compare stable isotope ratios among samples from different islands or between consumers. Means are reported \pm SE and differences were considered significant when $\mathrm{p}<0.05$. We used $\delta^{15} \mathrm{~N}$ values to estimate the trophic position of consumers. We assumed that Engraulis ringens were the main source of food for Otaria flavescens. Trophic position was estimated by using the formula:

trophic position $=$

$$
\lambda+\left(\delta^{15} N_{\text {consumer }}-\delta^{15} N_{\text {Engraulis ringens }}\right) / \Delta_{\mathrm{n}}
$$

where $\Delta_{\mathrm{n}}=3.4 \%$ is the estimated trophic fractionation (Post 2002) and $\lambda=2$ is the trophic position of E. ringens; we assumed these $\lambda$ values because $E$. ringens feed on primary producers at the base of the marine food chain (mainly diatoms, which we did not collect). We used average values (without SDs) of $\delta^{15} \mathrm{~N}_{\text {Engraulis ringens }}$ to simplify calculations. We applied this model to evaluate whether $\delta^{15} \mathrm{~N}$ values were consistent with our observations of Desmodus rotundus feeding on O. flavescens, and of the trophic interactions along the food chain connecting E. ringens to Trichobius parasiticus.

\section{RESULTS}

We observed Desmodus rotundus on all islands we visited between July 2003 and March 2005 (Table 1). We observed D. rotundus flying around Otaria flavescens individuals, groups or rookeries at Santa Rosa, La Vieja, Sangayan, Ballestas, Asia and Guañape islands, and $D$. rotundus feeding upon or walking near O. flavescens on Sangayan (see Fig. 1), Asia and Guañape islands. All feeding observations were made between 19:00 and 23:00 $\mathrm{h}$, except for Sangayan, where we observed $D$. rotundus approaching or feeding upon O. flavescens between 19:00 and 06:00 h during each visit.

During feeding events, Desmodus rotundus approached solitary individuals or individuals at the edge of the group or rookery, by walking or hopping among boulders. We observed $D$. rotundus biting the neck and feeding

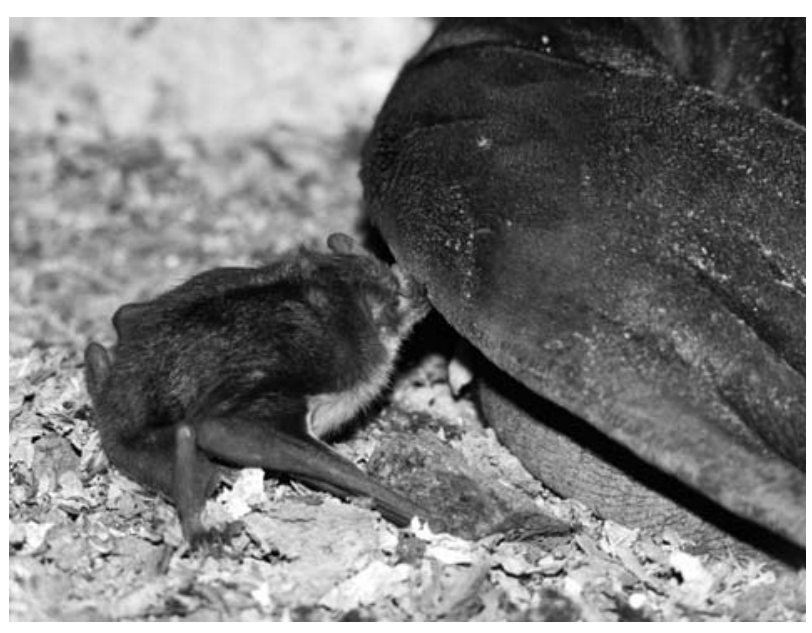

Fig. 1. Common vampire bat Desmodus rotundus feeding on young South American sea lion Otaria flavescens in Sangayan. Photo copyright Jim Clare, naturepl.com

upon Otaria flavescens individuals on Sangayan (several occasions in July, September and December 2003) and Asia (16 March 2005 at 21:00 h) islands. The individual shown in Fig. 1 is licking blood from the flipper of a young $O$. flavescens.

Values of $\delta^{15} \mathrm{~N}$ for Desmodus rotundus hair samples ranged between 19.52 and $20.51 \%$ and did not differ among islands $\left(F_{3,10}=2.76, \mathrm{p}=0.97\right.$; Table 2, Fig. 2). On Sangayan, $\delta^{15} \mathrm{~N}$ values of $D$. rotundus and Trichobius parasiticus were significantly more enriched than $\delta^{15} \mathrm{~N}$ values of Otaria flavescens $\left(F_{2,11}=57.58, \mathrm{p}<\right.$ 0.01 ; Tukey's post hoc test, $\mathrm{p}<0.01)$. T. parasiticus flies had $\delta^{15} \mathrm{~N}$ values more enriched than $D$. rotundus hair samples $(t=-5.87, \mathrm{p}<0.01)$. Anchovy had the lowest $\delta^{15} \mathrm{~N}$ values among all examined samples $\left(F_{3,12}=74.56\right.$, $\mathrm{p}<0.01$; Tukey's post hoc test, $\mathrm{p}<0.01)$. Estimated trophic positions were 2 for Engraulis ringens (assumed), $2.94 \pm 0.10$ for $O$. flavescens, $3.84 \pm 0.03$ for D. rotundus and $4.12 \pm 0.03$ for $T$. parasiticus.

Table 2. Carbon $\left(\delta^{13} \mathrm{C}\right)$ and nitrogen $\left(\delta^{15} \mathrm{~N}\right)$ stable isotope values for hair (Desmodus rotundus, Otaria flavescens) and tissue (Engraulis ringens, Trichobius parasiticus) samples collected on Peruvian guano islands

\begin{tabular}{|llccc|}
\hline Site & Sample & $\mathrm{N}$ & $\delta^{13} \mathrm{C} \pm \mathrm{SE}$ & $\delta^{15} \mathrm{~N} \pm \mathrm{SE}$ \\
\hline Santa Rosa I. & D. rotundus hair & 2 & $-12.02 \pm 0.18$ & $20.09 \pm 0.38$ \\
La Vieja I. & D. rotundus hair & 5 & $-12.28 \pm 0.17$ & $19.52 \pm 0.38$ \\
Sangayan I. & D. rotundus hair & 5 & $-11.65 \pm 0.07$ & $20.51 \pm 0.10$ \\
& D. rotundus feces & 5 & $-18.48 \pm 0.29$ & $20.63 \pm 0.52$ \\
& E. ringens & 2 & $-16.69 \pm 0.05$ & $14.24 \pm 0.61$ \\
& O. flavescens hair & 6 & $-15.05 \pm 0.17$ & $17.44 \pm 0.35$ \\
Ballestas I. & D. parasiticus & 3 & $-15.54 \pm 0.02$ & $21.44 \pm 0.11$ \\
& D. rotundus hair & 2 & $-11.66 \pm 0.05$ & $20.49 \pm 0.07$ \\
\hline
\end{tabular}




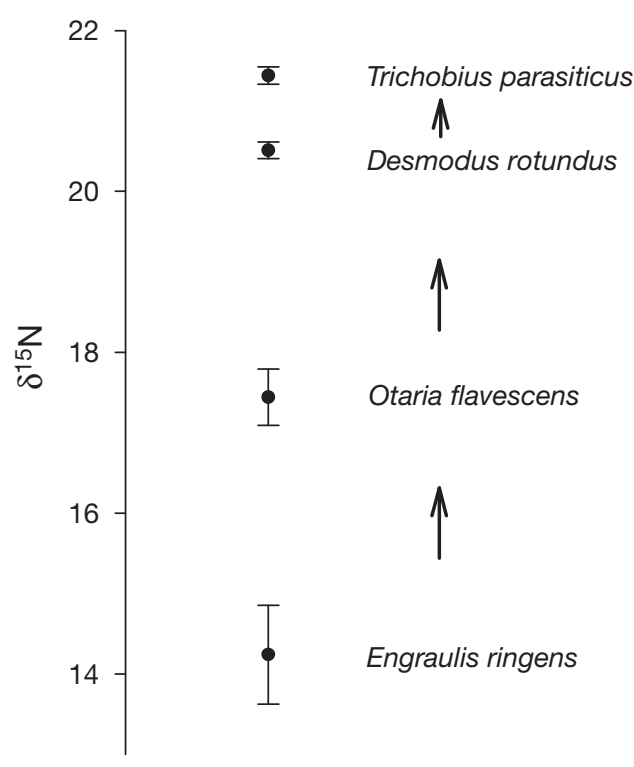

Fig. 2. Nitrogen stable isotope values of anchovy Engraulis ringens, South American sea lions Otaria flavescens, common vampire bats Desmodus rotundus and hippoboscid flies Trichobius parasiticus on Sangayan Island, Peru. Arrows indicate trophic interactions

Carbon isotopic values of Desmodus rotundus varied among islands $\left(F_{3,10}=5.38, \mathrm{p}=0.02\right)$, because hair samples from Sangayan were more enriched than those from Ballestas, La Vieja or Santa Rosa (Tukey's test, $\mathrm{p}=0.02)$. Values of $\delta^{13} \mathrm{C}$ from consumers on Sangayan varied widely $\left(F_{3,12}=220.25, \mathrm{p}<0.01\right)$ and ranged between -16.69 and $-11.65 \%$. The $\delta^{13} \mathrm{C}$ of hair samples in $D$. rotundus was more enriched than the $\delta^{13} \mathrm{C}$ of fecal samples collected at the same site $(t=$ 23.03, $\mathrm{p}=0.02$ ).

\section{DISCUSSION}

Enriched $\delta^{15} \mathrm{~N}$ in terrestrial animals frequently indicates that consumers are incorporating marine-derived nutrients in their diet (Stapp et al. 1999, Catenazzi \& Donnelly 2007b). The nitrogen isotopic ratios we report are much higher than those measured for Desmodus rotundus feeding mostly on cattle in Costa Rica (Voigt \& Kelm 2006b): $\delta^{15} \mathrm{~N}$ values averaged $11.5 \pm$ $1.1 \%$ in Costa Rica vs. $20.2 \pm 0.2 \%$ in coastal Peru. Therefore, our data support the idea that $D$. rotundus on Peruvian islands are obtaining most of their nitrogen from a marine source when they feed on Otaria flavescens.

The comparison of nitrogen isotopic ratios from consumers along a food chain (connecting Engraulis ringens to the bat ectoparasite Trichobius parasiticus) is consistent with the hypothesis that Otaria flavescens represents the primary food resource for Desmodus rotundus. Estimates of trophic position based on $\delta^{15} \mathrm{~N}$ values support our observations of $D$. rotundus feeding on O. flavescens, and previous references linking $E$. ringens to the diet of $O$. flavescens (Muck \& Fuentes 1987, Soto et al. 2006). Our stable isotope data also support the finding of Voigt \& Kelm (2006a) that T. parasiticus is a monoxenous parasite of $D$. rotundus, because the enrichment in $\delta^{15} \mathrm{~N}$ values between T. parasiticus and $D$. rotundus is consistent with a direct trophic interaction between these 2 consumers.

Carbon isotopic ratios were not helpful in elucidating the trophic interactions described above. Although we measured little variation in $\delta^{13} \mathrm{C}$ values of Desmodus rotundus hair samples among sites, there was a wide range of values for other members of the trophic chain. Fecal samples of $D$. rotundus, which are likely to integrate the diet over several weeks, also had lower $\delta^{13} \mathrm{C}$ values than hair samples. Differences in rates of tissue turnover and a 'stable isotope clock' effect could account for the wide variation in $\delta^{13} \mathrm{C}$ values between $D$. rotundus hair samples and tissue samples of other consumers (Fry 2006, Cerling et al. 2007).

Guano birds have previously been identified as hosts for Desmodus rotundus on Chilean (Luna-Jorquera \& Culik 1995) and Peruvian islands (Murphy 1925). However, the Chilean report was based on a single observation, and Murphy (1925) only supposed, when writing about 'extraordinary numbers of bats, at Asia, upon the Chinchas and at La Vieja, that cormorants and penguins were the main hosts of $D$. rotundus. During our visits, we did not observe $D$. rotundus feeding on birds, and we cannot speculate on their relative importance as hosts for D. rotundus. Of all Peruvian islands we visited, Sangayan was the only one lacking colonies of Peruvian boobies and Guanay cormorants, and yet we frequently observed $D$. rotundus feeding upon Otaria flavescens on Sangayan. Mann (1951) observed D. rotundus feeding at the ears of $O$. flavescens and occupying caves with sea lions on islands off the coast of northern Chile. Therefore, field observations of $D$. rotundus feeding on $O$. flavescens exist for several locations encompassing $>1000 \mathrm{~km}$ along the western coast of South America.

Several terrestrial consumers have been shown to take advantage of pinnipeds as conduits of marinederived resources, such as lions and hyenas in coastal Namibia (Bridgeford 1985, Roth et al. 2005), condors in California (Chamberlain et al. 2005), turkey vultures, arthropods, arachnids and lizards in coastal Peru (A. Catenazzi pers. obs.).

In conclusion, we have shown that Desmodus rotundus colonies are ubiquitous on Peruvian islands with Otaria flavescens rookeries, and that nitrogen stable 
isotope values are consistent with field observation of $D$. rotundus feeding on $O$. flavescens. This is yet another example of a terrestrial consumer that could not survive without marine input in the hyper-arid environment of the Peruvian coastal desert.

Acknowledgements. We thank the Reserva Nacional de Paracas for logistic support, the National Institute for Natural Resources (INRENA) for issuing research and collecting permits, PROABONOS and its staff for authorizing our visit to the guano islands, J. Carrillo for field assistance and M. Kershaw for processing samples for stable isotope analysis. We thank 4 anonymous reviewers who provided helpful comments that improved the manuscript. A.C. was funded by a Florida International University (FIU) Dissertation Year Fellowship and by grants from the Organization for Tropical Studies, the PADI Foundation, the American Museum of Natural History and the Tinker Field Research Grant. This is publication no. 133 of the Tropical Biology Program at FIU.

\section{LITERATURE CITED}

Bridgeford P (1985) Unusual diet of the lion Panthera leo in the Skeleton Coast Park. Madoqua 14:187-188

Catenazzi A, Donnelly MA (2007a) Distribution of geckos in northern Peru: long-term effects of strong ENSO events? J Arid Environ 71:327-332

Catenazzi A, Donnelly MA (2007b) The Ulva connection. Marine green algae subsidize terrestrial consumers in coastal Peru. Oikos 116:75-86

Cerling TE, Ayliffe LK, Dearing MD, Ehleringer JR and others (2007) Determining biological tissue turnover using stable isotopes: the reaction progress variable. Oecologia 151: 175-189

Chamberlain CP, Waldbauer JR, Fox-Dobbs K, Newsome SD and others (2005) Pleistocene to recent dietary shifts in California condors. Proc Natl Acad Sci USA 102: 16707-16711

Craig AK, Psuty NP (1968) The Paracas papers. Occasional publication, Department of Geography. Fl Atlantic Univ 1: $1-196$

Environmental Resources Management (2003) Reedición del Estudio de Impacto Ambiental y Social del Proyecto Planta de Fraccionamiento de Líquidos de Gas Natural e Instalaciones de Carga Playa Lobería, Pisco, Perú. Environmental Resources Management, Lima

Environmental Resources Management (2004) Informe Mensual Monitoreo Biótico y Abiótico para el Componente

Editorial responsibility: Matthias Seaman,

Oldendorf/Luhe, Germany
Marítimo Planta de Fraccionamiento Playa Lobería, Pisco, Perú. Environmental Resources Management, Lima

Fry B (2006) Stable isotope ecology. Springer, New York

Goodwin GG, Greenhall AM (1961) A review of the bats of Trinidad and Tobago: description, rabies infection, and ecology. Bull Am Mus Nat Hist 122:193-300

Greenhall AM (1988) Feeding behavior. In: Greenhall AM, Schmidt U (eds) Natural history of vampire bats. CRC Press, Boca Raton, FL, p 111-132

Koepcke HW, Koepcke M (1952) Sobre el proceso de transformación de la materia orgánica en las playas arenosas marinas del Perú. Publ Mus Hist Nat 'Javier Prado' Ser A (Zool) 8:1-24

Lord RD (1988) Control of vampire bats. In: Greenhall AM, Schmidt U (eds) Natural history of vampire bats. CRC Press, Boca Raton, FL, p 215-226

Luna-Jorquera G, Culik BM (1995) Penguins bled by vampires. J Ornithol 136:471-472

Mann FG (1951) Biología del vampiro. Biologica (Santiago) $12: 3-24$

Muck P, Fuentes H (1987) Sea lion and fur seal predation on the Peruvian anchoveta, 1953 to 1982. In: Pauly D, Tsukayamaeds I (eds) The Peruvian anchoveta and its upwelling ecosystem: three decades of change. ICLARM Studies and Reviews. Callao, Peru, p 234-247

Murphy RC (1925) Bird islands of Peru. Putnam's Sons, New York

Post DM (2002) Using stable isotopes to estimate trophic position: models, methods, and assumptions. Ecology 83: 703-718

Roth JD, Wiesel I, Drea CM (2005) Variation in seal consumption by brown hyenas in the Namib desert estimated using stable isotopes. Integr Comp Biol 45:1065

Soto KH, Trites AW, Arias-Schreiber M (2006) Changes in diet and maternal attendance of South American sea lions indicate changes in the marine environment and prey abundance. Mar Ecol Prog Ser 312:277-290

Stapp PT, Polis GA, Piñero FS (1999) Stable isotopes reveal strong marine and El Niño effects on island food webs. Nature 401:467-469

Tarazona J, Arntz W (2001) The Peruvian coastal upwelling system. In: Seeliger U, Kjerfve B (eds) Coastal marine ecosystems of Latin America. Springer, Berlin, p 229-244

Turner DC (1975) The vampire bats. Johns Hopkins University Press, Baltimore, MD

Voigt CC, Kelm DH (2006a) Host preferences of bat flies: following the bloody path of stable isotopes in a hostparasite food chain. Can J Zool 84:397-403

Voigt CC, Kelm DH (2006b) Host preference of the common vampire bat (Desmodus rotundus; Chiroptera) assessed by stable isotopes. J Mammal 87:1-6

Submitted: June 19, 2007; Accepted: December 3, 2007

Proofs received from author(s): April 30, 2008 